\title{
Fermentation of high concentrations of lactose to ethanol by engineered flocculent Saccharomyces cerevisiae
}

\author{
Pedro M. R. Guimarães · José A. Teixeira • \\ Lucília Domingues
}

Received: 13 May 2008/Revised: 27 May 2008/Accepted: 4 June 2008/Published online: 25 June 2008

(C) Springer Science+Business Media B.V. 2008

\begin{abstract}
The development of microorganims that efficiently ferment lactose has a high biotechnological interest, particularly for cheese whey bioremediation processes with simultaneous bio-ethanol production. The lactose fermentation performance of a recombinant Saccharomyces cerevisiae flocculent strain was evaluated. The yeast consumed rapidly and completely lactose concentrations up to $150 \mathrm{~g} \mathrm{l}^{-1}$ in either well- or micro-aerated batch fermentations. The maximum ethanol titre was $8 \%(\mathrm{v} / \mathrm{v})$ and the highest ethanol productivity was $1.5-2 \mathrm{~g} \mathrm{l}^{-1} \mathrm{~h}^{-1}$, in micro-aerated fermentations. The results presented here emphasise that this strain is an interesting alternative for the production of ethanol from lactose-based feedstocks.
\end{abstract}

Keywords Cheese whey - Ethanol production . Flocculent yeast - Lactose fermentation .

Recombinant S. cerevisiae

\section{Introduction}

The lactose in cheese whey, which is a by-product of dairy industries is generated in large amounts [about 91 (= $45 \mathrm{~kg}$ lactose) per $\mathrm{kg}$ cheese produced] and has

P. M. R. Guimarães · J. A. Teixeira · L. Domingues $(\bowtie)$ IBB - Institute for Biotechnology and Bioengineering, Centre of Biological Engineering, Universidade do Minho, Campus de Gualtar, 4710-057 Braga, Portugal e-mail: luciliad@deb.uminho.pt a high polluting load (Siso 1996), can be used as a substrate for bio-ethanol production by microbial fermentation. In addition, lactose fermentation strongly reduces the whey polluting load (Domingues et al. 2001; Siso 1996), contributing to resolution of the environmental problem created by whey surplus.

Direct fermentation of whey or whey permeate (i.e. the fraction remaining after protein recovery; Siso 1996) to ethanol is hardly economically competitive with the currently established processes (using cane sugar and cornstarch as substrates) or with emerging second generation technologies (using lignocellulosic biomass as raw material), mainly because the low lactose content (ca. 5\% w/v) results in low ethanol titre $(2-3 \% \mathrm{v} / \mathrm{v})$, making the distillation process too expensive. However, whey is a waste product and therefore has advantages over food-related fermentation feedstocks, such as corn. Moreover, whey ethanol has food-grade quality, and therefore can find alternative markets to fuel, e.g. in vinegar manufacturing and in the beverage industry. Concentration of whey lactose, e.g. by ultrafiltration, prior to fermentation is an option to obtain higher ethanol titres. Recently, Kargi and Ozmihci have proposed the use of cheese whey powder as an alternative source of concentrated lactose for the production of ethanol (Kargi and Ozmihci 2006; Ozmihci and Kargi 2007). The use of concentrated lactose solutions (up to about $200 \mathrm{~g}$ lactose $1^{-1}$ ) may permit ethanol titres up to $10-12 \%(\mathrm{v} / \mathrm{v})$, thus significantly reducing the distillation costs. However, 
existing microbial strains cannot ferment efficiently (i.e. rapidly and with high conversion yields) such high concentrations of lactose into ethanol.

Saccharomyces cerevisiae is usually the first choice for industrial processes involving alcoholic fermentation but this yeast is unable to metabolise lactose and, therefore, the lactose-consuming yeast, Kluyveromyces fragilis, has been used in most industrial plants producing ethanol from whey (Siso 1996). The engineering of S. cerevisiae for lactose utilization has been addressed over the past 20 years by different strategies (Rubio-Texeira 2006). However, most strains obtained displayed undesirable characteristics (such as slow growth, genetic instability or problems derived from the use of glucosegalactose mixtures) or were ineffective for ethanol production, as is the case of $S$. cerevisiae strains expressing the LAC4 ( $\beta$-galactosidase) and LAC12 (lactose permease) genes of Kluyveromyces lactis (Rubio-Texeira et al. 1998, 2000; Sreekrishna and Dickson 1985), with the exception of the strain used in this work.

Here, we describe fermentation of high concentrations of lactose (up to $200 \mathrm{~g} \mathrm{l}^{-1}$ ) to ethanol by a $S$. cerevisiae recombinant strain expressing the LAC4 and LAC12 genes of $K$. lactis. The aim was to investigate the highest initial lactose concentration that can be used in batch fermentation to obtain high ethanol titre and productivity while permitting complete lactose consumption, to develop a bioprocess for the simultaneous bioremediation of cheese whey and bio-ethanol production using this yeast strain. Aeration has been reported to improve the performance of yeast in fermentations producing very high concentrations of ethanol (see e.g. Alfenore et al. 2004). Therefore, two systems were tested in this work: wellaerated fermentations in a bubble column bioreactor and micro-aerated shake-flask fermentations.

\section{Materials and methods}

Yeast

The yeast used was a recombinant $S$. cerevisiae flocculent strain, NCYC869-A3/T1-E, expressing both the LAC4 and LAC12 genes of K. lactis from a multicopy plasmid. This strain is a derivative of the transformant NCYC869-A3/T1 (Domingues et al.
1999), and was obtained by a long-term evolutionary engineering experiment (Guimarães et al. 2008).

Media and fermentations

Fermentations were performed in the defined mineral medium described by Verduyn et al. (1992), but with doubled concentrations of trace elements and vitamins. The lactose was autoclaved separately $\left(110^{\circ} \mathrm{C}, 20 \mathrm{~min}\right)$ and added after heat sterilization of the medium $\left(120^{\circ} \mathrm{C}, 20 \mathrm{~min}\right)$ to $20-200 \mathrm{~g} \mathrm{l}^{-1}$, as indicated.

Bioreactor fermentations were done in a $600 \mathrm{ml}$ bubble column (made in-house) with H/D (height/ column diameter) ratio of 2.1 , filled with $400 \mathrm{ml}$ of defined mineral medium. The temperature and $\mathrm{pH}$ were maintained at $30^{\circ} \mathrm{C}$ and 4.0 , respectively, and air at $1 \mathrm{vvm}$ (adjusted and controlled by a mass flow controller) was applied using a sintered porous plate (with a diameter of $3 \mathrm{~cm}$ ) located at the bottom of the bioreactor. A magnetic stirrer was used to aid in keeping the entire reactor volume well-mixed. The yeast for inoculation was grown in $100 \mathrm{ml}$ Erlenmeyer flasks filled with $40 \mathrm{ml}$ of defined mineral medium containing $50 \mathrm{~g}$ lactose $\mathrm{l}^{-1}$. After incubation at $30^{\circ} \mathrm{C}$ and $150 \mathrm{rpm}$ for $20-30 \mathrm{~h}$, the cell suspension was aseptically pumped into the bioreactor to start the fermentation. The initial working volume after inoculation was therefore $440 \mathrm{ml}$.

Shake-flask fermentations were done in $500 \mathrm{ml}$ Erlenmeyer flasks filled with $200 \mathrm{ml}$ defined mineral medium and incubated at $30^{\circ} \mathrm{C}$ and $150 \mathrm{rpm}$. To avoid major drops in $\mathrm{pH}$ during cultivation the medium was supplemented with $100 \mathrm{mM}$ potassium hydrogen phthalate. The initial $\mathrm{pH}$ was adjusted to 5.5 with $\mathrm{NaOH}$. The final $\mathrm{pH}$ was higher than 4.3 in all fermentations. Pre-inocula were grown in $250 \mathrm{ml}$ Erlenmeyer flasks filled with $100 \mathrm{ml}$ of defined mineral medium containing $20 \mathrm{~g}$ lactose $1^{-1}$ for about $30 \mathrm{~h}\left(30^{\circ} \mathrm{C}, 150 \mathrm{rpm}\right)$, and appropriate volumes were used to inoculate the fermentations to an initial $\mathrm{OD}_{600}$ of $0.1-0.15$.

Analytical procedures

Yeast (biomass) growth was monitored as the $\mathrm{OD}_{600}$. The biomass was deflocculated by washing 2-5 times with $15 \mathrm{~g} \mathrm{NaCl}^{-1} \mathrm{pH} 3.0$ prior to $\mathrm{OD}_{600}$ measurements and correlated to the cell dry weight (DW) by 
a standard curve. DW was determined by filtering $10 \mathrm{ml}$ yeast culture through a pre-weighed $0.45 \mu \mathrm{m}$ filter and washing with $20 \mathrm{ml}$ water. The filter was dried overnight at $104^{\circ} \mathrm{C}$, cooled in a desiccator and weighed.

Lactose, ethanol and glycerol were analyzed by HPLC, using a Chrompack Organic Acids column. The column was eluted at $60^{\circ} \mathrm{C}$ with $0.005 \mathrm{M} \mathrm{H}_{2} \mathrm{SO}_{4}$ at $0.6 \mathrm{ml} \mathrm{min}{ }^{-1}$. A refractive-index detector was used.

\section{Determination of fermentation parameters}

Biomass conversion yield (Y) was calculated, at the time of lactose exhaustion, as: $\mathrm{Y}=$ biomass produced/lactose consumed. Ethanol conversion yield was calculated by the ratio between the maximum ethanol concentration produced and the initial lactose concentration. Ethanol yield was also expressed as a $\%$ of the theoretical yield, i.e. the yield considering a production of $0.538 \mathrm{~g}$ of ethanol per $\mathrm{g}$ of lactose consumed. Ethanol productivity was defined as the ratio between ethanol concentration and fermentation time.

\section{Results and discussion}

Figure 1 shows the profiles of biomass growth, lactose consumption and ethanol production during aerated batch fermentations with lactose ranging from 20 to $200 \mathrm{~g} \mathrm{l}^{-1}$. In all fermentations, lactose was completely consumed. The final biomass concentration increased with increasing initial lactose concentration, reaching approximately $20 \mathrm{~g}$ biomass $\mathrm{1}^{-1}$ for $200 \mathrm{~g}$ lactose $\mathrm{1}^{-1}$. The biomass conversion yield on lactose was highest $(0.19 \mathrm{~g}$ biomass $\mathrm{g}$ lactose $^{-1}$ ) with lactose at $20 \mathrm{~g} \mathrm{l}^{-1}$, strongly declining (to $0.07-0.10$ ) at higher lactose concentrations. The maximum ethanol concentration produced increased linearly with increasing initial lactose concentration (from $6.5 \mathrm{~g}$ ethanol $\mathrm{l}^{-1}$ with $20 \mathrm{~g}$ lactose $\mathrm{1}^{-1}$ to $57 \mathrm{~g}$ ethanol $1^{-1}$ with $200 \mathrm{~g}$ lactose $1^{-1}$ ). However, the ethanol yields were only $53-59 \%$ of the theoretical and are probably a result of the high aeration rates used in the bioreactor fermentations, resulting in biomass growth. The high air flow rate used was also motivated by operational reasons, i.e. to obtain bulk mixing, particularly of the flocculent biomass, in the bioreactor. The maximal ethanol productivity
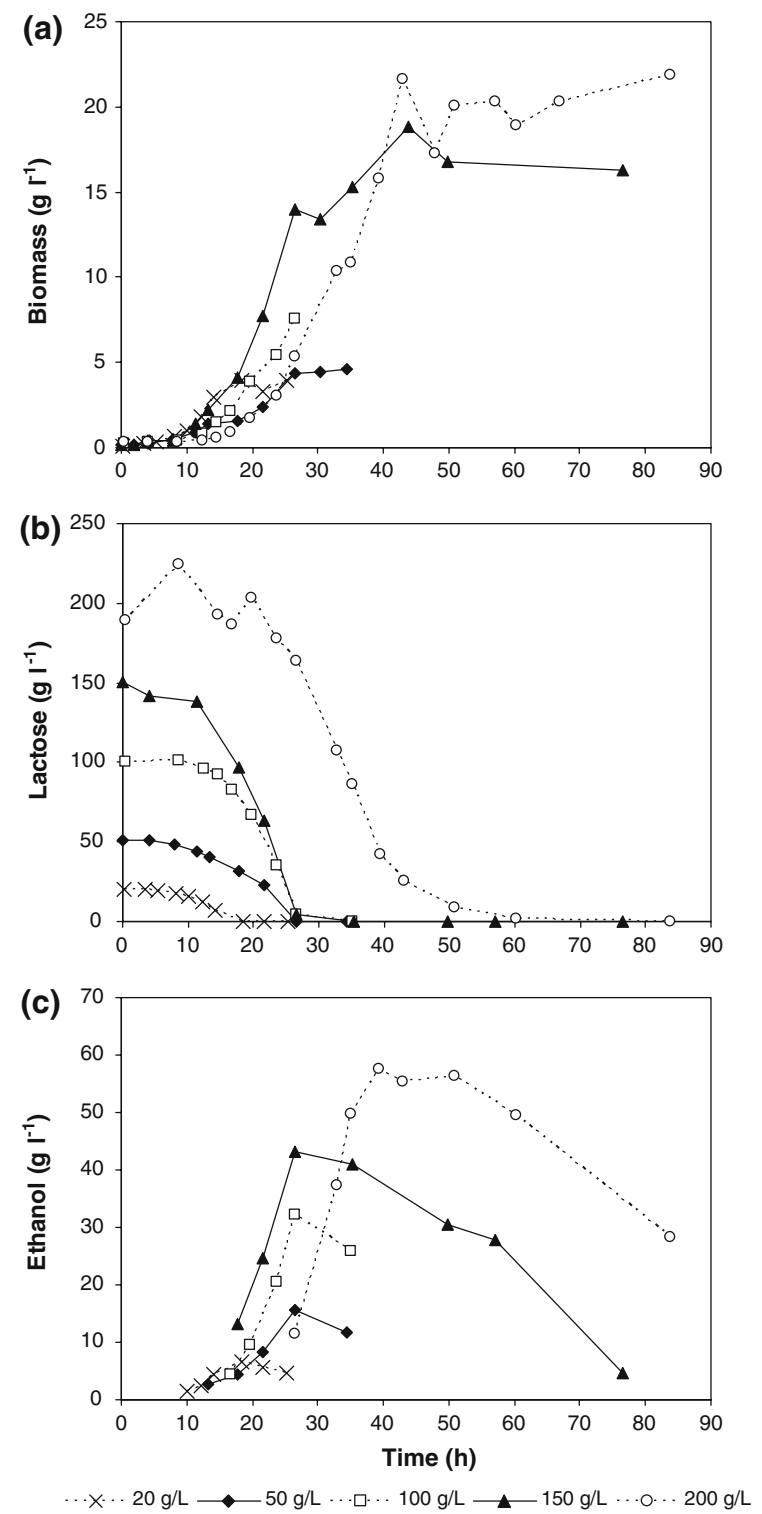

Fig. 1 Profiles of biomass growth (a), lactose consumption (b) and ethanol production (c) during fermentations in the bubble column bioreactor with initial lactose at approx 20, 50, 100, 150 and $200 \mathrm{~g} \mathrm{1}^{-1}$

increased with increasing lactose up to $150 \mathrm{~g} \mathrm{l}^{-1}$ (reaching $1.6 \mathrm{~g}$ ethanol $\mathrm{l}^{-1} \mathrm{~h}^{-1}$ for $150 \mathrm{~g}$ lactose $\left.\mathrm{l}^{-1}\right)$. Further increase in lactose to $200 \mathrm{~g} \mathrm{l}^{-1}$ did not improve productivity $\left(1.5 \mathrm{~g}\right.$ ethanol $\mathrm{l}^{-1} \mathrm{~h}^{-1}$ for $200 \mathrm{~g}$ lactose $\mathrm{1}^{-1}$ ).

Interestingly, the fermentations with $50-150 \mathrm{~g}$ lactose $1^{-1}$ reached completion in about the same time $(27 \mathrm{~h})$ and the highest ethanol concentration was reached at the point of lactose exhaustion. In the 
fermentation with $200 \mathrm{~g}$ lactose $\mathrm{l}^{-1}$, there was a longer (ca. $25 \mathrm{~h}$ ) lag phase for lactose consumption, possibly caused by substrate inhibition, followed by fast consumption (between around 25 and $40 \mathrm{~h}$ of fermentation) during which most lactose (ca. $140 \mathrm{~g} \mathrm{l}^{-1}$ ) was consumed. The highest ethanol concentration $\left(57 \mathrm{~g} \mathrm{l}^{-1}\right)$, ethanol conversion yield (68\% of the theoretical) and ethanol productivity $\left(1.5 \mathrm{~g} \mathrm{l}^{-1} \mathrm{~h}^{-1}\right)$ were reached at approximately $40 \mathrm{~h}$, when the residual lactose was still ca. $40 \mathrm{~g} \mathrm{l}^{-1}$. From that point on, lactose consumption was much slower, which may have been caused by product (ethanol) inhibition. Lactose exhaustion occurred only at about $60 \mathrm{~h}$, when the ethanol productivity was already much lower $\left(0.8 \mathrm{~g} \mathrm{l}^{-1} \mathrm{~h}^{-1}\right)$. The overall ethanol yield, considering the production of $57 \mathrm{~g}$ ethanol $\mathrm{l}^{-1}$ from $200 \mathrm{~g}$ lactose $1^{-1}$, was $53 \%$ of the theoretical value.

The recombinant strain was also tested in shakeflask fermentations with lactose at 150 and $200 \mathrm{~g} \mathrm{l}^{-1}$. The data obtained in duplicate fermentations with about $150 \mathrm{~g}$ lactose $1^{-1}$ are shown in Fig. 2. The yeast produced $55-59 \mathrm{~g}$ ethanol $\mathrm{l}^{-1}$ in about $28 \mathrm{~h}$. At this point, ethanol productivity was highest $\left(2 \mathrm{~g} \mathrm{l}^{-1} \mathrm{~h}^{-1}\right)$. However, there was still residual lactose at $17-34 \mathrm{~g} \mathrm{l}^{-1}$ which was further consumed attaining a final level of $<1.5 \mathrm{~g}$ lactose $1^{-1}$ after about $45 \mathrm{~h}$. At $40-45 \mathrm{~h}$, ethanol concentration was highest (ca. $63 \mathrm{~g} \mathrm{l}^{-1}$ ) but ethanol productivity had decreased to $1.5 \mathrm{~g} \mathrm{l}^{-1} \mathrm{~h}^{-1}$. The ethanol conversion yield was $78-84 \%$ of the theoretical yield. Figure 3 shows the fermentation profiles obtained with lactose

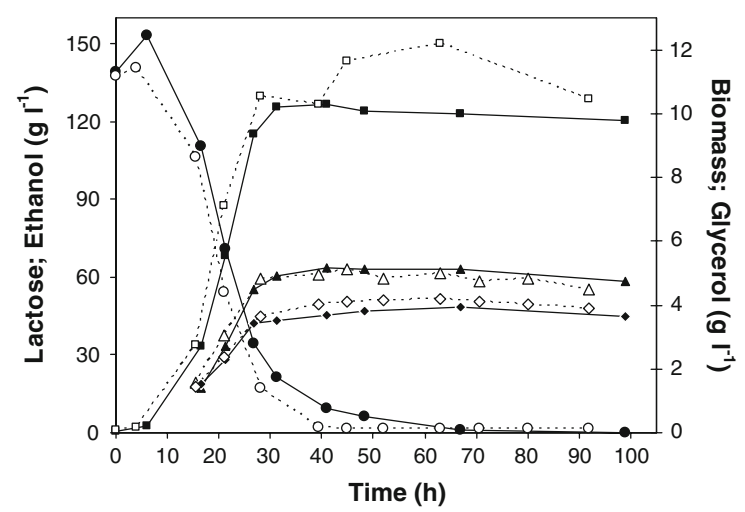

Fig. 2 Profiles of biomass $(\square ; \square)$ growth, lactose $(\mathbf{\square} ; \bigcirc)$ consumption, and ethanol $(\boldsymbol{\Lambda} ; \Delta)$ and glycerol $(\bullet ; \diamond)$ production during shake-flask fermentations with initial lactose at approx $150 \mathrm{~g} \mathrm{l}^{-1}$. Data from duplicate fermentations are shown at $200 \mathrm{~g} \mathrm{l}^{-1}$. Ethanol productivity was maximal $\left(1.7 \mathrm{~g} \mathrm{l}^{-1} \mathrm{~h}^{-1}\right)$ at $27 \mathrm{~h}$, corresponding to $46 \mathrm{~g}$ ethanol $1^{-1}$ with $95 \mathrm{~g}$ residual lactose $1^{-1}$. Ethanol was highest $\left(66 \mathrm{~g} \mathrm{l}^{-1}\right)$ after $48 \mathrm{~h}$ of fermentation, corresponding to a productivity of $1.4 \mathrm{~g} \mathrm{l}^{-1} \mathrm{~h}^{-1}$. Residual lactose at about $50 \mathrm{~g}^{-1}$ remained unconsumed. Yeast growth was only slightly slower with $200 \mathrm{~g}$ lactose $1^{-1}$ than that with $150 \mathrm{~g}$ lactose $1^{-1}$ (Figs. 2, 3). Expectedly, alcoholic fermentation was accompanied by glycerol biosynthesis (Figs. 2, 3), which has an essential role in maintaining yeast redox balance particularly under anaerobic growth conditions (Rigoulet et al. 2004).

The ethanol yields were much higher in the shake-flask fermentations (about $80 \%$ of the theoretical) than in the bioreactor fermentations $(<60 \%)$. This probably resulted from a lower $\mathrm{O}_{2}$ availability for yeast in the shake-flasks (conditions of microaeration), leading to higher sugar flux towards fermentative metabolism. In the shake-flasks, ethanol decreased only slightly after peak concentration (Figs. 2, 3), which may have resulted from evaporation. Under these conditions, $\mathrm{O}_{2}$ limitation probably impaired ethanol respiration after lactose depletion. Conversely, in the well-aerated bioreactor fermentations the ethanol decreased markedly after lactose exhaustion (Fig. 1c), most likely because it was consumed by the yeast cells by respiration.

In the design of processes for ethanol production from cheese whey or whey permeate a compromise must be made between maximisation of ethanol titre

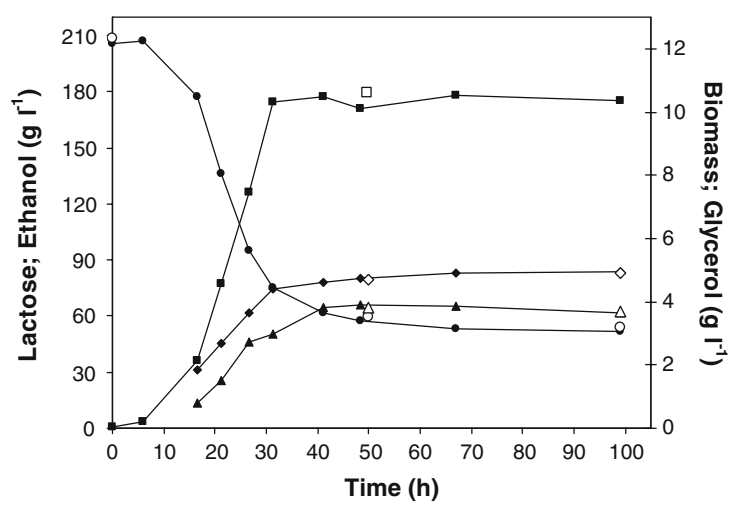

Fig. 3 Profiles of biomass ( $\square$ ) growth, lactose ( $)$ consumption, and ethanol $(\boldsymbol{\Delta})$ and glycerol $(\diamond)$ production during shake-flask fermentation with initial lactose at approx $200 \mathrm{~g}$ $1^{-1}$. Data from a duplicate fermentation (open symbols) are shown at 0,50 and $99 \mathrm{~h}$ 
and productivity and minimisation of the residual lactose concentration at the end of fermentation, since one of the major motivations for whey utilization is to reduce its polluting load. The recombinant $S$. cerevisiae strain used in this work consumed rapidly and completely $150 \mathrm{~g}$ lactose $\mathrm{l}^{-1}$ in either well-aerated (bioreactor) or micro-aerated (shakeflasks) batch fermentations, producing 5.5\% (v/v) and $8 \%$ (v/v) ethanol, respectively (Figs. 1, 2). However, the yeast was unable to consume $200 \mathrm{~g}$ lactose $1^{-1}$ completely in the micro-aerated shake-flask fermentations (Fig. 3) but, conversely, consumed totally the same concentration of lactose in well-aerated bioreactor fermentations (Fig. 1). This may be related with the yeast's inability to synthesize proper amounts of sterols and unsaturated fatty acids under the $\mathrm{O}_{2}$ limiting conditions found in the shake-flask fermentations. Yeasts need $\mathrm{O}_{2}$ to synthesise unsaturated fatty acids and sterols (see e.g. Guimarães et al. 2006) and lower amounts of these lipids in the plasma membrane have been correlated with lower ethanol tolerance (see Aguilera et al. 2006 and references therein). Nevertheless, the ethanol yields were considerably higher in the micro-aerated fermentations. Therefore, unlike reported by Alfenore et al. (2004), under our conditions high aeration was not beneficial to the ethanol production performance of the yeast. The results suggest that lactose initially at $150 \mathrm{~g} \mathrm{l}^{-1}$ represents the best compromise to obtain high ethanol titre $(8 \% \mathrm{v} / \mathrm{v})$ and productivity $\left(1.5 \mathrm{~g} \mathrm{l}^{-1} \mathrm{~h}^{-1}\right)$ at the end of fermentation (i.e. with residual lactose $<1.5 \mathrm{~g} \mathrm{l}^{-1}$ ).

The ethanol productivity obtained in this work was higher than that reported for batch or fed-batch fermentations with other lactose-consuming recombinant $S$. cerevisiae strains: $0.3 \mathrm{~g} \mathrm{l}^{-1} \mathrm{~h}^{-1}$ (Rubio-Texeira et al. 1998); 0.14-0.6 $\mathrm{g} \mathrm{l}^{-1} \mathrm{~h}^{-1}$ (Ramakrishnan and Hartley 1993); $1 \mathrm{~g} \mathrm{l}^{-1} \mathrm{~h}^{-1}$ (Compagno et al. 1995); $1.3 \mathrm{~g} \mathrm{l}^{-1} \mathrm{~h}^{-1}$ (Farahnak et al. 1986). The utilization of high initial lactose concentrations enabled also to attain higher ethanol titres than previously obtained with recombinant $S$. cerevisiae, with the exception of the work of Farahnak et al. (1986) that reported an ethanol titre of $13 \%(\mathrm{v} / \mathrm{v})$. The strain used here was also able to ferment concentrated cheese whey powder solution containing about $150 \mathrm{~g}$ lactose $1^{-1}$ in a batch fermentation with low $(0.1 \mathrm{vvm})$ aeration, consuming nearly all lactose (residual lactose $<3 \mathrm{~g} \mathrm{l}^{-1}$ ) in about $120 \mathrm{~h}$ and producing $7 \%$ (v/v) ethanol, which corresponds to an ethanol productivity of $0.46 \mathrm{~g} \mathrm{l}^{-1} \mathrm{~h}^{-1}$ (Guimarães et al. 2008). The performance of the yeast may be improved by supplementation of the cheese whey with cheap nutrient sources (e.g. corn steep liquor). Using Kluyveromyces marxianus to ferment concentrated cheese whey powder solution (about $150 \mathrm{~g}$ lactose $1^{-1}$ ), Kargi and Ozmihci (2006) obtained an ethanol titre of $10 \%(\mathrm{v} / \mathrm{v})$ but only after $216 \mathrm{~h}$ fermentation (productivity of $0.38 \mathrm{~g}$ ethanol $1^{-1} \mathrm{~h}^{-1}$ ). To our knowledge, the recombinant strain used in this work is the most efficient lactose-fermenting $S$. cerevisiae strain reported in the literature. This yeast fermented rapidly and completely high concentrations of lactose, which permitted a high ethanol titre with high productivity, therefore providing an attractive alternative for the fermentation of lactose-based media. An additional important advantage of this strain is its highly flocculent phenotype (see Guimarães et al. 2008). Flocculation can be regarded as a simple cell immobilization method (without the need for a support) allowing the retention of high concentrations of biomass inside a bioreactor. Therefore, this yeast strain is particularly suitable for the development of high cell density fermentation processes that, when operated in continuous with flocculated biomass retention, may allow to attain very high ethanol productivities (Domingues et al. 2000).

Acknowledgements We thank Jaroslav Klein for assistance in the bioreactor fermentations and Marisa Cunha for doing the HPLC analyses of some of the experiments. The financial support of Fundação para a Ciência e a Tecnologia (FCT), Portugal (project ProBioethanol PTDC/BIO/66151/2006) is acknowledged. P. M. R. Guimarães acknowledges support from FCT, Portugal (grant SFRH/BD/13463/2003).

\section{References}

Aguilera F, Peinado RA, Millán C, Ortega JM, Mauricio JC (2006) Relationship between ethanol tolerance, $\mathrm{H}^{+}$-ATPase activity and the lipid composition of the plasma membrane in different wine yeast strains. Int $\mathbf{J}$ Food Microbiol 110:34-42

Alfenore S, Cameleyre X, Benbadis L, Bideaux C, Uribelarrea J-L, Goma G, Molina-Jouve C, Guillouet SE (2004) Aeration strategy: a need for very high ethanol performance in Saccharomyces cerevisiae fed-batch process. Appl Microbiol Biotechnol 63:537-542

Compagno C, Porro D, Smeraldi C, Ranzi BM (1995) Fermentation of whey and starch by transformed Saccharomyces cerevisiae cells. Appl Microbiol Biotechnol 43:822-825 
Domingues L, Teixeira JA, Lima N (1999) Construction of a flocculent Saccharomyces cerevisiae fermenting lactose. Appl Microbiol Biotechnol 51:621-626

Domingues L, Vicente AA, Lima N, Teixeira JA (2000) Applications of yeast flocculation in biotechnological processes. Biotechnol Bioprocess Eng 5:288-305

Domingues L, Lima N, Teixeira JA (2001) Alcohol production from cheese whey permeate using genetically modified flocculent yeast cells. Biotechnol Bioeng 72:507-514

Farahnak F, Seki T, Ryu DD, Ogrydziak D (1986) Construction of lactose-assimilating and high ethanol producing yeasts by protoplast fusion. Appl Environ Microbiol 51: 362-367

Guimarães PMR, Virtanen H, Londesborough J (2006) Direct evidence that maltose transport activity is affected by the lipid composition of brewer's yeast. J Inst Brew 112:203209

Guimarães PMR, François J, Parrou JL, Teixeira JA, Domingues L (2008) Adaptive evolution of a lactose-consuming Saccharomyces cerevisiae recombinant. Appl Environ Microbiol 74:1748-1756

Kargi F, Ozmihci S (2006) Utilization of cheese whey powder (CWP) for ethanol fermentations: effects of operating parameters. Enzyme Microb Technol 38:711-718

Ozmihci S, Kargi F (2007) Kinetics of batch ethanol fermentation of cheese-whey powder (CWP) solution as function of substrate and yeast concentrations. Biores Technol 98:2978-2984
Ramakrishnan S, Hartley BS (1993) Fermentation of lactose by yeast cells secreting recombinant fungal lactase. Appl Environ Microbiol 59:4230-4235

Rigoulet M, Aguilaniu H, Averet N, Bunoust O, Camougrand N, Grandier-Vazeille X, Larsson C, Pahlman IL, Manon S, Gustafsson L (2004) Organization and regulation of the cytosolic NADH metabolism in the yeast Saccharomyces cerevisiae. Mol Cell Biochem 256-257:73-81

Rubio-Texeira M (2006) Endless versatility in the biotechnological applications of Kluyveromyces LAC genes. Biotechnol Adv 24:212-225

Rubio-Texeira M, Castrillo JI, Adam AC, Ugalde UO, Polaina J (1998) Highly efficient assimilation of lactose by a metabolically engineered strain of Saccharomyces cerevisiae. Yeast 14:827-837

Rubio-Texeira M, Arevalo-Rodriguez M, Lequerica JL, Polaina J (2000) Lactose utilization by Saccharomyces cerevisiae strains expressing Kluyveromyces lactis LAC genes. J Biotechnol 84:97-106

Siso MIG (1996) The biotechnological utilization of cheese whey: a review. Biores Technol 57:1-11

Sreekrishna K, Dickson RC (1985) Construction of strains of Saccharomyces cerevisiae that grow on lactose. Proc Natl Acad Sci USA 82:7909-7913

Verduyn C, Postma E, Scheffers WA, van Dijken JP (1992) Effect of benzoic acid on metabolic fluxes in yeasts: a continuous-culture study on the regulation of respiration and alcoholic fermentation. Yeast 8:501-517 